\title{
Influence of Managerial Communication to Performance of Small and Middle-sized Enterprises
}

\author{
Petr ז̌EHOŘ, Jaroslav VRCHOTA \\ University of South Bohemia, České Budějovice, Czech Republic \\ \{rehor, vrchota\} @ef.jcu.cz
}

\begin{abstract}
A long-term effort of the management of an organization is permanent financial performance, which means profit. Any manager of small and medium-sized enterprises looks for suitable strategies that will enable them to succeed in a competitive environment. Most often, they focus on common reducing costs, increasing market share, introducing new products, strengthening relationships with customers and retaining talented staff in the organization. Some managers, however, still do not realize that communication is the most important tool for improving the organization's performance. Currently, the communication process is no longer only the exchange of information. It is the basis of influencing prosperity of the organization and its competitiveness. In any organization, communication of managers is both a factor that unites people who work in it and participate differently on its performance, and partly a factor that actively participate in all management processes. The communication is used to the goals set in the strategies for evaluation and monitoring, and particularly it is important in the field of human relations. Undoubtedly, it is the cornerstone of the success of any organization. Both the internal communication for operational decisions and the communication of strategic decisions are of great importance to improving the performance of SMEs and optimize their management. Effective communication link setup is not only important for the consistency of all work activities, but also for stimulating job performance, work behaviour, motivation and employee loyalty. The paper deals with the influence of managerial communication to the performance of 148 SMEs.
\end{abstract}

Keywords: Communication, Management, Performance, SMEs, Plan, Strategy.

\section{$1 \quad$ Introduction}

The communication belongs to the most difficult skills which are necessary for efficient performance of managerial functions. Internal communication is one of the most complex processes which must be kept on running, that is why it is necessary to make the information available for everybody in due time [24]. Clear, open communication between management and human resources lies in an understandable description of the current situation of the organization, in the exact determination of goals and ways to achieve them [23]. 
Concerning communication it is important to know how to: solve problems and develop new skills, deal with conflicts, emotions and anger, understand other people, adapt, change and grow [20]. Organizational researchers have suggested that communication is particularly important in organizational change processes $[13,30]$. Within the communication, human communication almost always consists of verbal and nonverbal signals that are mutually supportive [7].

Today, communication is mostly understood in the sense of sharing and transferring information [27]. Communication is the process by which meanings are exchanged between people through the use of an agreed system of symbols [1]. It is a process of mutual transfer of information in social contact governed by certain rules [15]. Communication is a way by which changes can be achieved providing the welfare of an organization. It is important for the internal functioning of an enterprise as it integrates management functions [8]. Communicative interactions in the workplace serve to create and maintain work relationships among team and organizational member [18]. Success of a company is based on the knowledge how to treat the information [17].

Managerial communication contains of both interpersonal communication, communication between two or more persons, and communication within an organization, which covers all the models, networks and communication systems within the organization [21]. Managerial communication is the exchange of information between the executive and all stakeholders (especially employees and customers) [22]. It concerns exchanging information from top as well as from bottom, via formal and informal channels through which it is possible to reach objectives that manager designate [29].

Managerial communication performs in organizations at the initiative of the management team with the direct involvement of the management team, in order to achieve practical the strategic objectives [26]. Managerial communication includes all relevant forms and communication channels that the manager can choose for accomplishing his or her objectives [5]. Bell and Martin [4] define managerial communication as the downward, horizontal, or upward exchange of information and transmission of meaning through informal or formal channels that enables managers to achieve their goals. In practice these communication skills are required: competence in listening and answering, openness and sincerity, inquiry, empathy, negotiation and solving conflicts [16].

There are many reasons why we should deal with the managerial communication. A research of Watson Wyatt Worldwide, a multinational consulting company, from the last decade of North American companies confirmed that a well-functioning internal communication means measurable financial benefits and other quantifiable benefits for profit-oriented organizations [28]. Petř́íková et al. [19] notes, that according to this study, companies with efficiently organized internal communication financially win over companies that do not have this organization. The study results clearly demonstrate that communication is a key element in creating successful business dealings.

The ultimate goal of an organization is to maximize stakeholders value and profitability, which is accomplished by integrating strong leadership with formal and 
informal communication networks [2]. In particular, communication that reveals shared values and reflects common commitments to organizational goals enables coworkers to forge and sustain productive relationships in organizations [10]. Communication can also have direct and indirect effects on team and organizational performance [9].

Effective communication has also been identified as a significant factor in helping employees understand the need for change, as well as the personal effects of a proposed change [3]. Quality and therefore effective communication improves employee efficiency, helps managing the flow of information, provides feedback to managers, develops a sense of belonging and the team spirit, and it is also good preparation for the crisis management [6]. Not accepting communication as authority can be a major obstacle to the improvement of organizational performance, innovation and change efforts [14].

A sign of a good functioning of the managerial communication is that the company employees' information and motivation are well-integrated. Workers have sufficient information for their work; they know what is expected of them. One of the most important prerequisites for good functioning is regular feedback in both directions [11]. Overall, malfunctioning of the communication in an organization often results in the following:

- high rate of staff turnover, poor coordination of work processes and activities,

- staff disinterest in achieving the goals,

- determination inappropriate strategy based dysfunctional feedback,

- ineffective marketing management,

- inability of competing in the market [25].

Both general and specific measures of the assessment of efficiency of the communication can be found in three areas: loyalty and employee satisfaction, the overlap between formal and informal communication, customer satisfaction [12].

\section{$2 \quad$ Methods}

This text aims to assess the impact of managerial communication in small and medium-sized enterprises of the South Bohemian Region in Czech Republic for their performance and propose recommendations that would make the internal communication more effective.

Quantitative economic data was obtained from annual reports and income statements according to the identification number (ICO) of companies that were involved in the survey (interview with managers), which was implemented in 20132014 by the students of the Faculty of Economics at the University of South Bohemia in České Budějovice. The interview consisted of many questions, for the purposes of this paper, only two were selected (plan, strategy). To verify the influence of communication on the performance, the author of the text used the financial statements of the sample of 176 SMEs in South Bohemian region, which had been published on the Internet. From the group Organizations that recorded no data for the 
indicators of the assessment (profit and performance/1 employee) were also eliminated. The final sample numbered 148 SMEs.

Information processing used the methods of descriptive statistic as the interval screening and a simple sorting of data. In the tables of frequencies, absolute frequency and relative frequency are set. The values of relative frequencies are reported as a percent of the total. Data were processed using statistical methods suitable for analysis of categorical data, which are a part of the Statistica program. Statistical evaluation of the survey results used programming environment that provides simple tabulations, graphs and procedures for data analysis. It was used for univariate analysis and qualitative characteristics of addiction.

Testing of the dependence of the impact of the communication on a sample of financial indicators

The first step in statistical testing is always a statistical hypothesis formulation, i.e. the formulation of research questions to form the null and the alternative statistical hypotheses that are placed when tested against each other. The null hypothesis H0 states that the communication indicators do not affect the performance (the financial indicators). This statement usually expresses no or zero difference between the test data sets. If the calculated $\mathrm{p}$-value is less than the error probability of one kind $\alpha$ (0.05), then we reject the null hypothesis and accept the alternative hypothesis Ha, when we say that there is an effect on performance. The alternative hypothesis denies the validity of the HO null hypothesis. Typically, it is expressed as the difference between the files or the existence of dependence between the variables.

\section{$3 \quad$ Results}

\subsection{Planning in managerial communication and human resource management}

The planning is one of the most important functions for the managers. It should result into a detailed plan of future activities in an organization. A plan is a written document that defines the objectives, strategies to achieve them, the need and the amount of resources, time schedule and responsibilities of the people involved. By the table 1, drawing up the plan in managerial communication does not address the absolute majority of examined SMEs in the Region of South Bohemia (51\%). Smaller half of the managers establish communication goals and plans, but we do not know if the plans are written.

Table 1. Do the SMEs in the Region of South Bohemia set a plan?

\begin{tabular}{lcc}
\hline Do you have plan? & $\mathrm{n}$ & $\%$ \\
\hline Yes & 72 & 48.65 \\
No & 76 & 51.35 \\
Total & 148 & 100 \\
\hline
\end{tabular}


Worse condition was detected in human resources management process. Surprisingly (see table 2), more than $60 \%$ of SMEs in the Region of South Bohemia does not have a strategy. The remaining organizations can establish a long-term direction in this area. In this issue, the managers thus have considerable reserves. They should deal with future development and to prepare plans, objectives and strategies in the areas of human resources management and communication, in which the employees could be also involved. Written plans would increase the awareness of people in the workplace and thus increasing their workload.

Table 2. Do the SMEs in the Region of South Bohemia set a strategy for the HRM?

\begin{tabular}{lcc}
\hline Do you have HRM strategy? & $\mathrm{n}$ & $\%$ \\
\hline Yes & 54 & 36.49 \\
No & 94 & 63.51 \\
Total & 148 & 100 \\
\hline
\end{tabular}

Profit/loss is the accounting term for the difference between revenues and costs of the organization and represents the profit or loss for a given period or periods. For a more comprehensive comparison, the profit was calculated per one employee. Within the sample of 148 organizations, almost half of the SMEs reached a positive economic result, i.e. the profit per one employee in the interval from 0 to 100 thousand CZK (see table 3). On the contrary, more than a quarter of organizations showed a loss. Around $7 \%$ of SMEs reached the profit of more than 300 thousand CZK per one employee.

Table 3. The profit/loss per one employee in the SMEs of the Region of South Bohemia in CZK.

\begin{tabular}{lcc}
\hline & $\mathrm{n}$ & $\%$ \\
\hline$-500000<\mathrm{x}<=-100000$ & 10 & 6.76 \\
$-100000<\mathrm{x}<=0$ & 25 & 16.89 \\
$0<\mathrm{x}<=100000$ & 74 & 47.97 \\
$100000<\mathrm{x}<=200000$ & 23 & 15.54 \\
$200000<\mathrm{x}<=300000$ & 8 & 5.41 \\
over 300000 & 11 & 7.43 \\
Total & 148 & 100 \\
\hline
\end{tabular}

Output means the products that an organization creates and manages to place them on the market or that are in various stages of production (unfinished, work in progress, semi-finished products) or other performances created in the custom mode for their own consumption. Around $2 / 5$ of organizations (see table 4 ) reached the output per 1 employee up to 1 million CZK. Up to 2 million CZK was reached by other $1 / 3$ organizations. The sample also revealed approximately $5 \%$ of the organizations with the output of more than 5 million CZK. Outputs in the SMEs in the Region of South Bohemia were below negative. 
Table 4. The output per one employee in the SMEs of the Region of South Bohemia in CZK.

\begin{tabular}{lcc}
\hline & $\mathrm{n}$ & $\%$ \\
\hline $0<\mathrm{x}<=1000000$ & 58 & 39.19 \\
$1000000<\mathrm{x}<=2000000$ & 54 & 36.49 \\
$2000000<\mathrm{x}<=3000000$ & 17 & 11.49 \\
$3000000<\mathrm{x}<=4000000$ & 11 & 7.43 \\
over 4000000 & 8 & 5.41 \\
Total & 148 & 100 \\
\hline
\end{tabular}

To test the dependence of categorical variables, the Statistica General Linear Model was used. It is a method of studying dependence of the explained variable to the explaining variables. At first, the explained variable was the profit calculated per one employee and the explaining variables were the existence of a strategy and communication plans. As reported by the table 5, the p-value of no variable was less than 0.05 . We failed to prove dependence. We can therefore conclude that the variables do not affect the profit of organizations per one employee. The communication in an organization therefore does not have an important role.

Table 5. Univariate tests of significance for profit of organizations per one employee.

\begin{tabular}{lcc}
\hline & $\mathrm{F}$ & $\mathrm{p}$ \\
\hline Do you have a strategy? & 0.000856 & 0.976702 \\
Do you prepare plans? & 1.909147 & 0.169228 \\
\hline
\end{tabular}

In the second testing, the explained variable was the indicator of performance per one employee. There were the same explaining variables. By the table 6 , the p-value was greater than the $\alpha$ level of significance. As we cannot reject the null hypothesis H0, so that we suppose it applies. There we failed to prove the dependence. For the variable of "Do you have an HRD Strategy?", the p-value was reported less than 0.05 . In this single indicator, a dependence on the performance per one employee was proved. A strategy for human recourses has a significant effect on the performance.

Table 6. Univariate tests of significance for performance per employee.

\begin{tabular}{lcc}
\hline & $\mathrm{F}$ & $\mathrm{p}$ \\
\hline Do you have a strategy? & 4.926130 & 0.028039 \\
Do you prepare plans? & 0.928392 & 0.336919 \\
\hline
\end{tabular}

\section{$4 \quad$ Discussion}

\subsection{Making plans, objectives and strategies}

The process of human resource management and communication should be based on a detailed strategic plan. Unfortunately, creating strategies separately has been implemented by only in a small number of SMEs in South Bohemia Region so far. 
In organizations that have a strategy in HRM dependence, and therefore its impact on the standard of performance, was statistically proven. As a part of the strategic planning of human resources management, the management of organizations should ask the following questions: What direction do they want to develop their organization and human resources? What goals should they determine? What are the strategies to achieve them? What is the strength or weakness of the process of HRM? What educational projects do they want to implement? How should they finance? What kind of subsidy should they apply for? How should they engage employees? What influences from outside is threatening? How should they effectively communicate with their employees? What should be the best way to participate in all activities?

To determine their weaknesses, it is appropriate to prepare a SWOT analysis and manage its activities in such a way that the weaknesses in human resources and particularly problematic communication with employees are gradually dismantled. All proposals should be a part of the strategic plan and should be tackled with the highest priority by the financial situation.

Each organization should compile and update their strategic plans, not only in the field of human resources management, but also in the communication process, and not to react to it after forced by competitors. Management of SMEs can therefore recommend the creation of a communication strategy and communication plan as part of a HRM strategic plan (such as meetings, consultations, conflict resolutions, teamwork principles, ways of exchanging information). The Strategy will define the information flow (who informs, who to inform, how and how often). The declaration and subsequent uniform enforcement in terms of management of the organization is vitally important.

Each plan should be updated every year, mainly on the basis of feedback from the previous annual operation. The feedback of employee is important such as to allow them to enter into the decision to develop an organization and themselves; and the feedback of managers, such as to continuously evaluate their subordinates, to commend them for a job well done. The management should conduct regular audits, which would measure the effectiveness of internal communication and continually educate and train the managers in communication, negotiation, assertiveness and conflict resolution, since the manager is the communication link which promotes plans and objectives of the organization to the work of each employee.

\subsection{Transmission of information within the organization}

Many SMEs try to achieve the full performance of both the organization and the human resources. It is possible to achieve this state only provided that workers are adequately informed and motivated, resulting in their identification with the organization and its goals. Employees need information to their proper and effective work. They need to know the goals of the organization and its strategy. They should be kept informed about what is successful and what is not. They should know their specific tasks and other duties. Determination of understandable objectives is an essential prerequisite for successful communication. The more people can identify 
with the outlined goals and strategies of an organization, the closer they are to their actual fulfillment. Any management action should lead to the use of all available communication channels and opportunities for continuous exchange of information between managers and workers. Lack of information is not only of a negative impact on work performance when the employee does not have sufficient data for the job, but the information is also linked with the need for certainty. Therefore, all workers should be familiar enough with what is happening in the organization, what are its future goals and strategies. Concealment of information or their deficiency leads to communication noise.

The management of organizations can implement information tools, such as the periodic publication of newspapers, journals and newsletters or regular updates on the intranet. To have an effective communication within the organization, a regular feedback in both directions is also necessary. It is not just that workers receive proper and updated information about everything that affects them directly, but they should also be allowed to express their comments, opinions or possible dissatisfaction. Most often, they can do so through workshops or contacting their immediate supervisor. It is also possible to use a regular survey that investigates the needs and wishes of employees and their overall satisfaction with the work procedures, management, and communication. Using questionnaires should be tailored according to specific requirements of the organization. It is a relatively quick and affordable method for collecting data. Other improvements are the introduction of further means of internal communication in the form of anonymous boxes that contribute to better information management or hearing request, statements, questions and opinions of employees. It can also be a written communication of thinks that are difficult to be said such as being a witness of bullying in the workplace, sexual harassment or conflict with colleagues and direct superiors.

\section{Conclusion}

The ability of managers and employees, superiors and subordinates, communicate together openly and effectively is one of the critical success factors of organizations. The communication between these groups is a source of information that both need to operate efficiently and effectively. Any manager should focus primarily on the sufficient level of awareness of its employees about the company's goals, plans and prospects for further development. The manager deals with people successfully only if they can create an atmosphere of mutual trust, sense of belonging to the team, but also to explain and present the goals and objectives of the organization, to build a creative climate where everyone feels team member feels important and necessary for the successful operation the entire team and an organization in general.

Internal communication is a totally unnecessary weakness of most SMEs. The management underestimates its importance and often does not deal with the basic settings. Doing so, the correct setting of communication within an organization is a significant stabilizing factor in difficult times. So that management can effectively manage the organization needs faster and more accurate method of communication, 
which in turn provides a better ground for cooperation in business a competitive advantage in bringing cost savings and increased revenues for the organization.

The management must work with internal communication as with an important strategic tool to get employees to meet objectives and to gain their loyalty. Only loyal employee can live their own strategies and expertise and contribute by their added value. Effective communication is the engine rather than the result of financial performance and greater employee involvement. Organizations with high levels of communication often have more committed employees and lower staff turnover compared to other organizations. Effective communication within an organization is a strong sign of the maturity of its internal culture and the daily levels of managerial work. Influence of the strategies on the performance of the SMEs was statistically proven in this text.

Acknowledgements. This paper was supported by GAJU 79/2013 / S and GAJU 053/2016/S

\section{References}

1. Adair, J.: Jak se správně rozhodovat a řešit problémy. Brno: Computer Press (2007).

2. Ahmed, Z., Shields, F., White, R. and Wilbert, J.: Managerial communication: the link between frontline leadership and organization performance. Journal of organizational culture, communications and conflict, 14(1), pp. 107-120 (2010).

3. Armenakis, A. and Harris, S.: Crafting a change message to create transformational readiness. Journal of organizational change management, 15(2), pp. 169-183 (2002).

4. Bell, R.L., Martin, J.: The promise of managerial communication as a field of research. International journal of business and public administration, 5(2), pp. 125-142 (2008).

5. Brownell, J.: Applied Research in Managerial Communication: The Critical Link between Knowledge and Practice. Available at: http://business.highbeam.com/4074/article-1G1101938452/applied-research-managerialcommunication-critical (2003).

6. Bystrov, V., Růžička, M.: Firemní komunikace a řízení reputace. Brno: Masarykova univerzita, Fakulta sociálních studií (2006).

7. DeVito, J.A.: Základy mezilidské komunikace. Praha: Grada (2008).

8. Fiedler, J., Horáková, J.: Komunikace v řízení. Praha: Česká zemědělská univerzita v Praze (2005).

9. Greenbaum, H.H., Query, J.L.: Communication in organizational work groups. In L.R. Frey (Ed.) The handbook of group communication theory and research (pp. 539-564). Thousand Oaks, CA: Sage (1999).

10. Herriot, P.: Selection and self: selection as a social process. European journal of work and organizational psychology, 11, pp. 385-402 (2002).

11. Hloušková, I.: Vnitrofiremní komunikace. Praha: Grada (1998).

12. Holá, J.: Interní komunikace ve firmě. Brno: Computer Press, a.s. (2006).

13. Lewis, L.: Disseminating information and soliciting input during planned organizational change: Implementers'target, sources, and channels for communication. Management communication quarterly, 13(1), pp. 43-77 (1999).

14. Longenecker, C.O., Fink, L.S.: Improving management performance in a rapidly changing organization. Journal of management development, 20(1), pp. 7-18 (2001). 
15. Mikuláštík, M.: Komunikační dovednosti v praxi. Praha: Grada Publishing. (2010).

16. More, E., Irwin, H.: Management communication for the new millennium. Available at: http://search.proquest.com/docview/216290593/fulltextPDF/13336811BB943F1992/33?ac countid=9646 (2000).

17. Mounter, P., Smith, L.: Effective internal communication. London: Kogan Page Ltd. (2008).

18. Myers, K.K.: Workplace relationships. In S. Smith and S.R. Wilson (Eds.) New directions in interpersonal communication (pp.135-156). Thousand Oaks, CA: Sage (2009).

19. Petrríková a kol.: Lidé v procesech řízení. Praha: Professional Publishing (2007).

20. Philips, A.: Communication and the manager's job. Oxford: Radcliffe Publishing (2002).

21. Robbins, S.P., Coulter, M.: Management. Praha: Grada Publishing (2004).

22. Řehoř, P.: Manažerská komunikace. České Budějovice: Ekonomická fakulta, Jihočeská univerzita v Českých Budějovicích (2012).

23. Řehoř, P.: Komparace manažerské komunikace ve vybraných soukromých a veřejných organizacích. In Hittmár, Štefan a kol. (Ed.) Management trends in theory and practice. Žilina: EDIS (2013).

24. Řehoř, P., Doležalová, V., Březinová, M. Communication with employees in human resources management proces in SMEs. In International Conference Hradec Economic Days 2015, pp. 152-157 (2015).

25. Urban, J.: Řízení lidí $\mathrm{v}$ organizaci: personální rozměr managementu. Praha: ASPI Publishing, s. r. o. (2003).

26. Voinea, D.V., Busu, O.V., Opran, E.R., Vladutescu, S.: Embarrassments in managerial communication. Polish journal of management studies, 11(2), pp. 171-180 (2015).

27. Winkler, J.: Komunikace v organizacích. Brno: Masarykova univerzita (1998).

28. Yates, K.: Internal communication effectiveness enhances bottom-line results. Journal of organizational excellence, pp. 71-79 (2006).

29. Zia, A, et al.: Managerial communication: the link between frontline leadership and organizational performance. Available at: http://www.thefreelibrary.com/Managerial+communication\%3A+the+link+between+frontl ine+leadership+and...-a0235623724 (2010).

30. Zorn, T., Page, D., Cheney, G.: Nuts about change: Multiple perspectives on changeoriented communication in a public sector organization. Management communication quarterly, 13(4), pp. 515-566 (2000). 